Debarshi Bhattacharya, 2018

Volume 4 Issue 2, pp.1166-1187

Date of Publication: 17 th September 2018

DOI-https://dx.doi.org/10.20319/pijss.2018.42.11661187

This paper can be cited as: Bhattacharya, D. (2018). Study on Impact of Execution of LBA, 2015 on the Erstwhile Enclaves' People of India and Bangladesh. PEOPLE: International Journal of Social Sciences, $4(2), 1166-1187$.

This work is licensed under the Creative Commons Attribution-NonCommercial 4.0 International License. To view a copy of this license, visit http://creativecommons.org/licenses/by-nc/4.0/ or send a letter to Creative Commons, PO Box 1866, Mountain View, CA 94042, USA.

\title{
STUDY ON IMPACT OF EXECUTION OF LBA, 2015 ON THE ERSTWHILE ENCLAVES’ PEOPLE OF INDIA AND BANGLADESH
}

\section{Debarshi Bhattacharya}

Associate Professor, Dept. of Commerce, S. R. Fatepuria College, University of Kalyani, West

Bengal, India

ratulbhat@yahoo.co.in

ratulbhat07@gmail.com

bursar@srfatepuriacollege.in

\begin{abstract}
Enclaves in India and Bangladesh were dire outcome of historical partition of India in 1947. Inhabitants within enclaves of both the countries were forced to live in 'no-man's land' as 'nowhere people' till 67 years after India's independence and partition. They were discriminatorily deprived from getting basic amenities, rights, opportunities and governmental supports until signing of the historic Land Boundary Agreement (LBA) between India and Bangladesh in 2015. As per LBA, 2015, 51 Bangladeshi enclaves inside India and 111 Indian enclaves inside Bangladesh were actually transferred to each other w.e.f. July 31, 2015 midnight. A study was undertaken through extensive field survey in various erstwhile enclaves of both the countries to assess real impact of LBA, 2015 on the status of erstwhile enclaves' people. During said study, entire population of these enclaves cordially welcomed exchange of enclaves through LBA, 2015, as they got rid of their exiled life of long 67 years by means of LBA, 2015. But even after execution of LBA, 2015, major problematic issues in these erstwhile enclaves had not yet been resolved; nor had rehabilitation packages so far been implemented for them.
\end{abstract}




\section{Keywords}

Enclaves, Exchange of Enclaves, Enclave Settlement Camp, Land Boundary Agreement (LBA)

\section{Introduction}

Not very faraway, just around three years back, there were some slivers of territory within independent India and Bangladesh, where country's independence defined its people differently, resulting in creation of a separate class of 'stateless people' within these two neighboring countries. On a fine morning, a country had been divided into two parts, intersecting hearts of a section of marginal people trapped in the dire consequence of creation of a porous border which virtually seized countless golden days from their lives, making them marginalized "enclaves' people" only. Although these people were not at all responsible for their such awful kismet; yet they were forced to live in 'no-man's land' as 'nowhere people' till 67 years after India's independence and partition just due to derision of historical and political destiny. These ill-fated people were the people of enclaves of India and Bangladesh with a combined population of more than 53,000 (Bhattacharya, 2017).

Enclave or exclave (Chhitmahal in Bengali language) refers to a portion of territory of one country, which is totally separated from its mainland, completely surrounded by the territory of a foreign country. More clearly, the land geographically completely separated from its mainland and is fully cordoned by a foreign state(Bhattacharya, A Rarely Told Gloomy Saga of Resurrected Nowhere People Earlier Lived in No-man's Land, 2017). "From the point of view of the state in which it is located, is termed as an enclave and the state to which it belongs to is an exclave"'(Schendel, 2005). But for the purpose of the study undertaken, two terms enclave and exclave are used synonymously. It is interesting to note that most of the enclaves of the world laying in India and Bangladesh during the recent past; although enclaves occurred frequently throughout the history and particularly Western Europe was rich in enclaves. Physically, enclaves in India and Bangladesh were found in three different formats, such as '1st-order enclave';'2nd-order enclave' or 'counter-enclave' (i.e. enclave within an enclave) and '3rd-order enclave' or 'counter-counter enclave' (i.e. an enclave laying within a counter-enclave). As per Report of the India-Bangladesh Joint Field Inspection, apart from one non-exchangeable Bangladeshi enclave inside Indian territory,111 exchangeable Indian Enclaves inside Bangladesh and 51 exchangeable Bangladeshi Enclaves inside India had been identified (Report, 1996). These included a few '2nd-order enclaves' or 'counter-enclaves' as well as a '3rd-order enclave' 
or 'counter-counter enclave' (i.e. a Bangladeshi enclave surrounded by an Indian enclave, which itself surrounded by another Bangladeshi enclave). All these exchangeable 162 enclaves in India and Bangladesh contained a total population of 53,384(MEA, Exchange of Enclaves between India and Bangladesh, 2015). In India, all these splinters of Bangladesh were positioned in the District of Coochbehar under the State of West Bengal. On the other hand, in Bangladesh, these flakes of India were located in its four Districts under Rangpur Division, of which 59 were situated in Lalmonirhat District, 36 were in Ponchogarh District, 12 were in Kurigram District and 4 were in Nilphamari District(Jugantor, 2015).These disjointed territories within the two countries created an inhuman situation for the enclaves' people and they were compelled to sustain their existence under a hardnosed situation of statelessness without any state aid and support from either side.

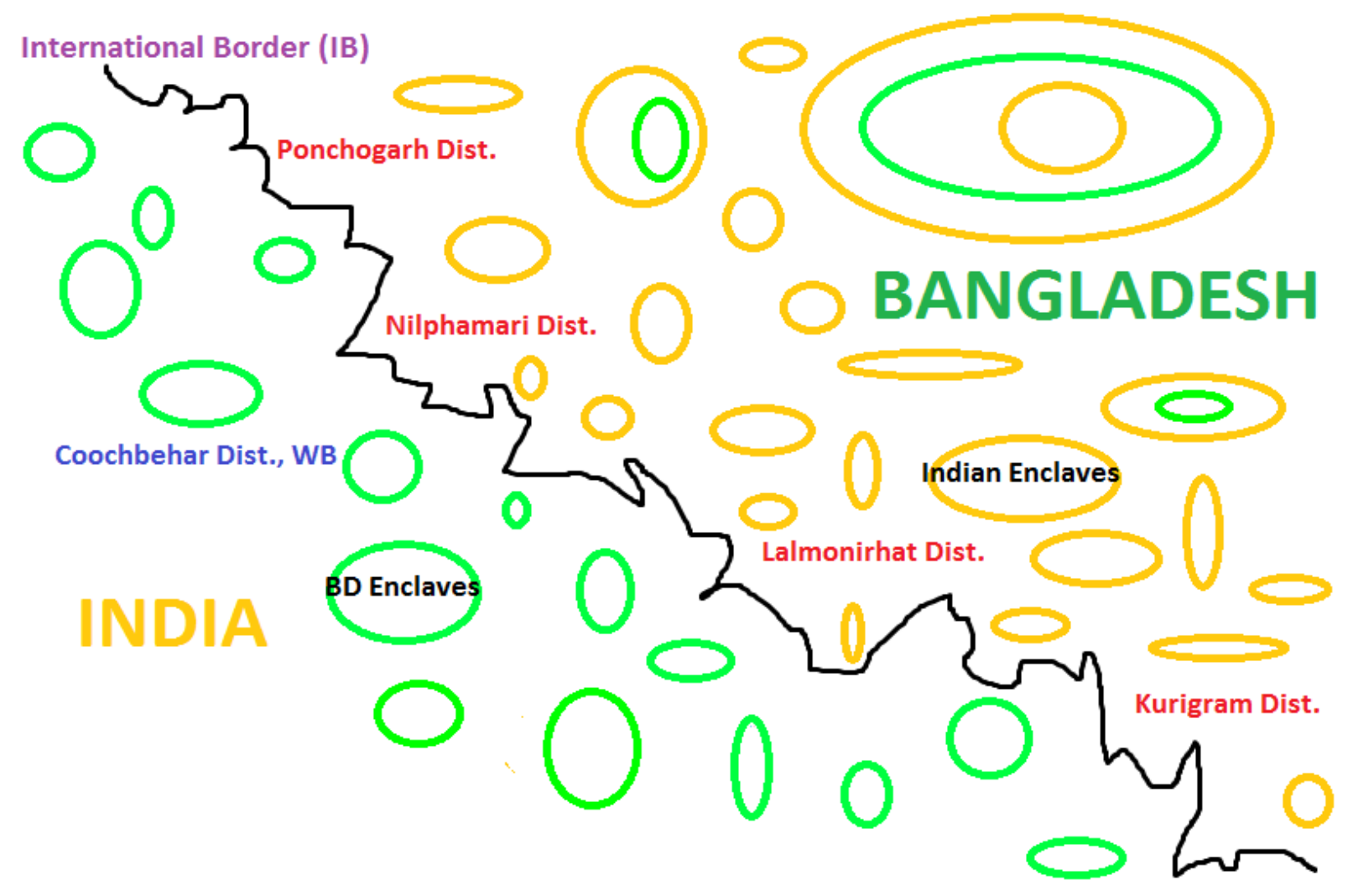

Copyright reserved by Author

Figure 1: Map of Enclaves

Apart from these, there were 35 Indian Lands under Adverse Possession of Bangladesh and 42 Bangladeshi Lands under Adverse Possession of India (Faculty of Studies, 2001). There were several places along the Indo-Bangladesh Border, where lands falling on Indian side of the demarcated International Boundary (IB) [i.e. De-jure Boundary] were actually occupied by 
Bangladesh (i.e. Indian land under Bangladesh occupation) and vice versa (i.e. Bangladeshi land under Indian occupation). Thus, the de-facto boundary (i.e. actual line of control) didn't not coincide with the de-jure boundary (i.e. demarcated International Boundary) in practice. Land falling between the de-jure and the de-facto boundary is called 'Adverse Possession'(Chatterjee, 2011). In India, these 'adverse possessions' were located in the states of Assam, Meghalaya, Tripura, and West Bengal.

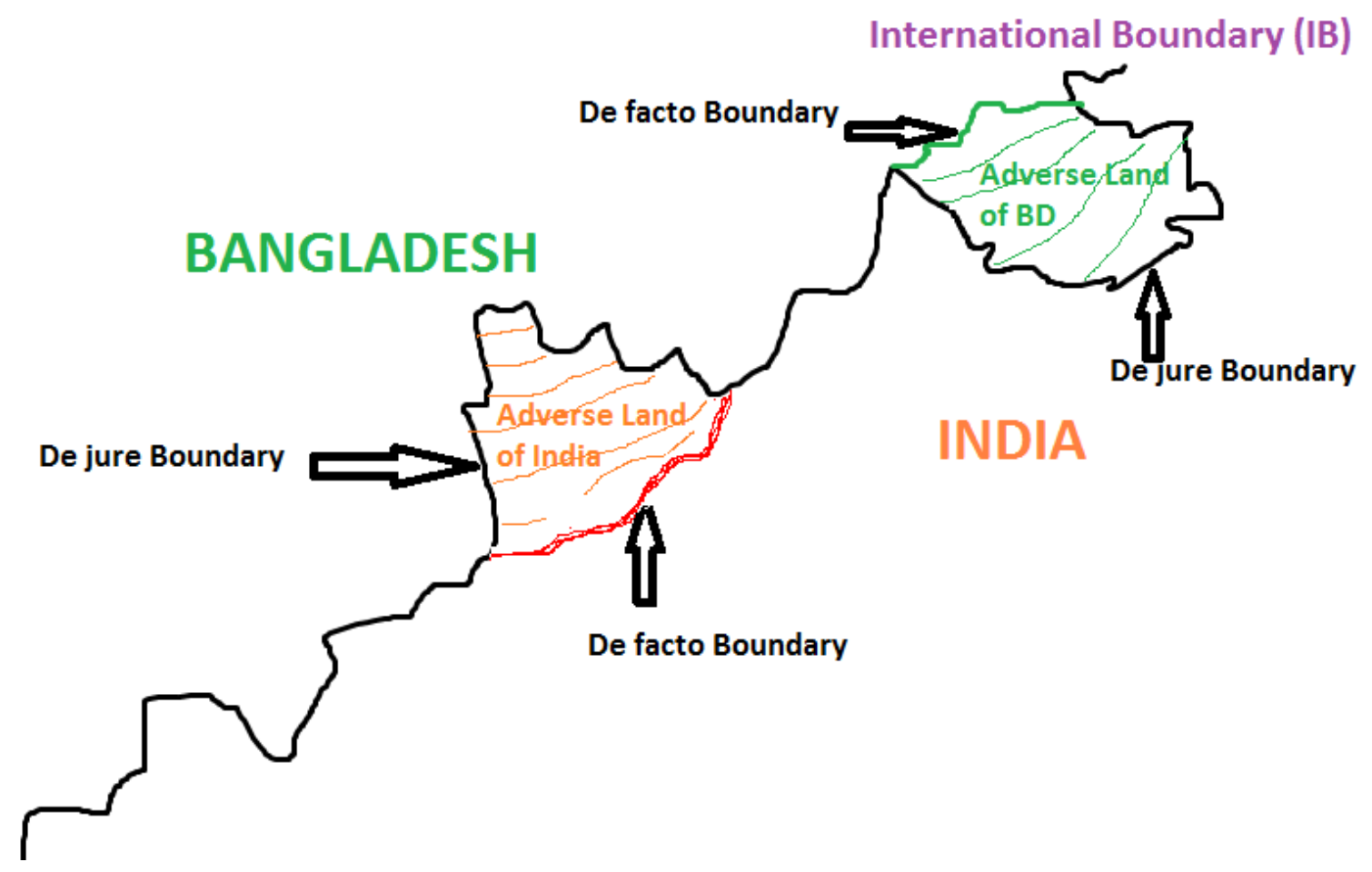

Copyright reserved by Author

Figure 2: Map of Adverse Possession

Inhabitants of these enclaves of both the countries sustained their lives without any state support, constitutional rights and basic amenities for their livelihoods year after year. Being completely surrounded by the territory of aforeign state, they couldn't even travel to their 'mother land' by crossing the territory of the foreign state. On the other hand, Governmental support system of the mother state couldn't get any access to these enclaves due to the barrier of international boundary (IB) in between. Thus, inhabitants of enclaves had been discriminatorily deprived from Governmental services, essential facilities and basic opportunities for their livelihoods from their native state for long 67 years after India's independence and partition until signing of the historic Land Boundary Agreement (LBA) between India and Bangladesh in the 
year 2015, by means of which these ill-fated people got rid of their long exiled lives within enclaves.

\section{Backdrop of the Study}

History itself intertwined destiny of some of our co-citizens in snide wires. Now-a-days, erstwhile enclaves of India and Bangladesh are of course contiguous part of India or Bangladesh; but till 67 years after India's independence and partition, these places were mere fragmented territories of India and Bangladesh completely surrounded by the other country. These enclaves were emerged for a variety of historical, political and geographical reasons. Undivided India was never a one-state. There were so many princely states within the Indian subcontinent, which neither the Mughals nor the British could bring under their direct control. On the other hand, it had been evident that the imperial rulers often allowed semi-autonomous Zamindari estates or princely states to grow in the frontier areas in order to ensure security to the far-flung areas. Throughout the middle ages, especially during the Mughal era, there were so many detached territories in the Indian subcontinent belonging to one Raja or Zamindar, entirely surrounded by the territories of others' jurisdictions. Thus, the origin of most of the enclaves in India and Bangladesh can be traced to the relics of the pre-colonial era. In the Indian side, enclaves were found only in the District of Coochbehar of the state of West Bengal, which were formerly under the ruling jurisdictions of the Maharaja of Rangpur. On the other hand, enclaves were found only in a small and narrow section of the northern boundary of Bangladesh within its present Districts of Kurigram, Lalmonirhat, Nilphamari and Panchogarh. These areas were under the jurisdiction of the King of Coochbehar during the Mughal period. Creation of these enclaves thus contains a long historical backdrop, when Shahjahan was the Mughal Emperor and Raja Prananarayana was the King of Coochbehar Estate. Raja Prananarayana occupied certain portion of territory within the Mughal territory by defeating Mughal Emperor. Thus, the King of Coochbehar ruled over some portion of lands which were completely surrounded by lands belonging to the Mughal Empire. Similarly Mughals also wrested some portion of territory within the Coochbehar Estate, which later came under the rule of the Maharaja of Rangpur(Studyacer, 2010). So, these territories were geographically separated from the Coochbehar and Rangpur Estates, ruled by one emperor within the jurisdiction of the other's Estate. Erstwhile Indian enclaves, those now situate inside Bangladesh, were the property of the King of Coochbehar before India's independence and partition. Similarly, erstwhile Bangladeshi enclaves, those now lay inside 
India, were the property of the Maharaja of Rangpur prior to India's independence and partition. By the late 17th century, the Mughals, capitalizing on the palace tension of Coochbehar, waged a number of invasions in the Kingdom and annexed three of its southern districts namely Kakina, Kazirhat and Fatehpur(Rabbani, 2005-06). The disputes between the Mughals and the King of Coochbehar continued until 1713, when a treaty was signed between the two. Under the treaty, Coochbehar ceded those three districts and in addition, it also lost its sovereignty over three further districts of Boda, Patgram and Purvabhag. These districts were not integral areas, rather contained pockets of other zamindari that remained under the sovereignty of Coochbehar estate. Likewise, there were some pockets of land within the territory of Coochbeher belonging to Boda, Patgram, and Purvabhag(Rabbani, 2005-06). This led to the emergence of a number of enclaves in India and Bangladesh. In this context, some advocate otherwise. According to an unverified popular legend, these slices of land were used as stakes in card or chess games or other gambling centuries ago between two regional kings, the Raja of Coochbehar and the Maharaja of Rangpur. There was also hearsay about the origin of these enclaves that if some of the local Raja entered the neighbouring territories for recreation or hunting as royal guests and pitched tent in some place, that area was given to him as a mark of honour or to strengthen their friendship. "In 1947, when the British finally left India after almost two centuries, they created two countries, India and Pakistan, out of one. In order to partition the country, they brought in a lawyer, Cyril Radcliffe, to demarcate the boundary between India and what was to become Pakistan, who demarcated the India-Pakistan border in straightlines cutting across territories" (Butalia, 2002). The fact that the two Estates of Coochbehar and Rangpur chose not to join either India or Pakistan at the time of Independence also played a significant role in the process of creation of these enclaves. In 1949, Coochbehar joined India and in 1952, Rangpur chose to be part of Pakistan. "What posed a problem was the fact that over the time, they had been conquering each other's territories" (Kaur, 2002). Combined effect of all these incidences resulted in creation of enclaves of India inside Bangladesh and vice-versa.

Governmental endeavour to 'de-enclave' was firstly manifested through Nehru-Noon Agreement in 1958 by means of exchange of enclaves between India and the then Pakistan, but the matter then hanged for a Supreme Court case in India. With reference to said 1958Agreement, negotiations were resumed after East Pakistan became an independent country as Bangladesh in 1971. In 1974, the Indira-Mujib Treaty of Friendship was supposed to address all land border disputes between India and Bangladesh, who shared 4,096.7 kms long porous 
border in between. Both countries were able to conclude the LBA, 1974 to find out an ultimate resolution to this complex nature of border demarcation except for the three outstanding issues pertaining to: (i) Exchange of enclaves; (ii) Settlement of adverse possession; (iii) Undemarcated land boundary of approximately $6.1 \mathrm{kms}$. in three sectors, viz. Daikhata-56 in West Bengal, Muhuri River-Belonia in Tripura and Lathitila-Dumabari in Assam (MEA, Land Boundary Agreement Protocol between India and Bangladesh, 2011).

Exchange of enclaves redrawing of the international boundary and to maintain status quo of adverse possessions, India required a constitutional amendment according to Article 368 of its Constitution. Although Bangladesh duly ratified said agreement, but India then failed to pass necessary constitutional amendment in its Parliament to ratify said agreement. In September, 2011, Governments of India and Bangladesh announced, by virtue of Monomohan-Hasina Land Boundary Agreement, an intention to resolve the issue by means of swapping 162 enclaves, allowing choices of selection of their nationality to enclaves' residents. In India, One Hundred and Nineteenth Constitution Amendment Bill, 2013 put forward to give effect to this proposed land exchange. But India again failed to pass necessary constitutional amendment in its Parliament to approve said agreement (Encyclopedia, 2010).

After several postponements and delay in settlement of the appalling destiny of the people of these enclaves, their wretched destiny of long almost seven decades came to an end when India ratified the Land Boundary Agreement with Bangladesh by its 119th Constitutional Amendment in May 2015 in both the houses of its Parliament. Immediately thereafter, 111 Indian enclaves in Bangladesh (covering an area of 17,160.63 acres) and 51 exchangeable Bangladeshi enclaves in India (covering an area of 7,110.02 acres) along with 35 Indian Lands under Adverse Possession of Bangladesh (covering an area of 2267.682 acres) and 42 Bangladeshi Lands under Adverse Possession of India (covering an area of 2,777.038 acres) (MEA, India-Bangladesh Land Boundary Agreement, 2015) had been exchanged between the two countries by virtue of historic Land Boundary Agreement (LBA) accorded between the Govt. of Republic of India and the Govt. of Peoples' Republic of Bangladesh on 6th June, 2015 with only one exception. Dohogram-Angarpota, the twin Bangladeshi Enclave situated in Mekhligunj Block under Coochbehar District of West Bengal, India, covering a total area of 18.68 sq. kms. with a combined population of around 20,000 has not been exchanged and it still remains as an integrated part of Bangladesh as per resolution adopted through LBA, 1974, although it is completely surrounded by Indian territory (Bhattacharya, Study on Impact of 
Exclusion of Exchange of Dohogram-Angarpota Bangladeshi Enclave from the Coverage of Land Boundary Agreement, 2015, 2017).

As per LBA, 2015, 111 Indian enclaves in Bangladesh and 35 Indian Lands under Adverse Possession of Bangladesh henceforth be treated as own lands of Bangladesh; whereas 51 exchangeable Bangladeshi enclaves in India and 42 Bangladeshi Lands under Adverse Possession of India henceforth be considered as own lands of India. Accordingly, 51 Bangladeshi enclaves in India and 111 Indian enclaves in Bangladesh were theoretically transferred to the other country with effect from the midnight of 31 July 2015. Such exchange of lands is basically a switch from a de-facto situation to a de-jure one, since these enclaves and adverse possessions were already occupied by the respective country. By virtue of LBA, 2015 Protocol, people residing in these enclaves were free to choose their nationality as per their own will. If they decided to stay in their birth soil by altering their citizenship (e.g. if a person of Indian enclave residing within Bangladesh territory opted to stay in Bangladesh as a Bangladeshi Citizen), they would get all benefits of citizenship of the concerned state where they opted to live. On the other hand, if they wished to migrate themselves into their mother state (e.g. if a person of Indian enclave residing within Bangladesh territory opted to migrate in Indian mainland), they would also get all benefits of citizenship of the mother state in the concerned mainland. The concerned mother state would offer adequate rehabilitation packages to such people in their mainland (Bhattacharya, Land Boundary Agreement, 2015 between India and Bangladesh - a Post-Implementation Analysis from India's Perspective, 2017). It had been highly expected from all the corners that "this long overdue exchange would endeavour to harmonize India's land boundaries and, more importantly, would improve the lives of all those residents of the enclaves who, by an unfortunate twist of fate, had been living without any national identity and without enjoying or ever knowing the quality of life enjoyed by their neighbours living just around these enclaves" (Das, 2013). In the meantime, almost three years have already been passed after execution of LBA, 2015. The undergoing study is an honest endeavour to explore the present reality of the issue.

\section{Objectives of the Study}

With the objective of assessing ground level real impact of execution of LBA, 2015 on the status of the people of erstwhile enclaves in India and Bangladesh, I carried out an extensive field survey during the years 2015, 2016 and 2017 in enclaves of both the countries. Survey had 
been conducted on random sampling basis in large, medium and small size enclaves of India and Bangladesh and interacted with enclaves' people of all ages, genders and religions. Following were the brief objectives of my study:

(i) To assessthe satisfaction levels of enclaves' people about their decision regarding choice of citizenship by virtue of LBA, 2015.

(ii) To assess the satisfaction levels of enclaves' people about the exchange deal and rehabilitation packages offered to and so far implemented for them.

(iii) To identify and assessthe extent of infrastructural developmental works initiated by the concerned state within the erstwhile enclaves under respective jurisdiction.

(iv) To assess andexplore the real impact of exchange of enclaves through LBA, 2015 among erstwhile enclaves' people of India and Bangladesh.

\section{Methodology and Materials}

The undertaken study involved both primary and secondary data collected from various sources including empirical analysis of field survey data and analysis of literature survey. The data used for empirical analysis were collected from field survey at erstwhile enclaves in form of personal interaction, interviews, group discussion and answers to the questionnaires. Secondary data were collected from Govt. reports / press releases, reports of previous researchers, concerned experts' opinions, articles, books, print and electronic media, internet sources etc.

Out of total 51 erstwhile Bangladeshi Enclaves inside Indian territory, 17 enclaves of different sizes and population bases were randomly chosen for the field survey purpose conducted in May, 2015, June, 2016 and May, 2017 at Mekhligunj, Mathabhanga, Sitalkuchi and Dinhata Blocks under Coochbehar District of West Bengal, India. Survey had been conducted with total 312 inhabitants of Bangladeshi enclaves inside India of all ages, genders and religions.

Details of 17 erstwhile Bangladeshi enclaves in Indian territorychosen for field surveypurposeare shown below under Table 1.

Table 1: Details of Bangladeshi Enclaves inside Indiavisited during the field survey

\begin{tabular}{|l|l|l|l|l|l|}
\hline $\begin{array}{l}\text { Name of erstwhile } \\
\text { Bangladeshi enclaves visited }\end{array}$ & $\begin{array}{l}\text { Physically located in the } \\
\text { Block of Coochbehar } \\
\text { District, WB, India }\end{array}$ & $\begin{array}{l}\text { Under the } \\
\text { jurisdiction } \\
\text { of Bangladeshi } \\
\text { Police } \\
\text { Station } \\
\text { District }\end{array}$ \\
1. Dhabalsati Mirgipur & Mekhligunj & $\begin{array}{l}\text { DL } \\
\text { No. } \\
\text { Latgram, } \\
\text { Lalmonirhat }\end{array}$ & $\begin{array}{l}\text { Area in } \\
\text { acres }\end{array}$ & $\begin{array}{l}\text { Interacted } \\
\text { with No. of } \\
\text { Persons in } \\
\text { the enclave }\end{array}$ \\
\hline 2. Balapukhari & Mekhligunj & Patgram, & 21 & 331.64 & 25 \\
\hline
\end{tabular}




\begin{tabular}{|c|c|c|c|c|c|}
\hline & & Lalmonirhat & & & \\
\hline 3. Chhit Kuchlibari & Mekhligunj & $\begin{array}{l}\text { Patgram, } \\
\text { Lalmonirhat }\end{array}$ & 22 & 370.64 & 23 \\
\hline 4. Chhit Panbari & Mekhligunj & $\begin{array}{l}\text { Patgram, } \\
\text { Lalmonirhat }\end{array}$ & 18 & 108.59 & 7 \\
\hline 5. Dhabalsati & Mekhligunj & $\begin{array}{l}\text { Patgram, } \\
\text { Lalmonirhat }\end{array}$ & 13 & 60.45 & 5 \\
\hline 6. Jotto Nijjama & Mekhligunj & $\begin{array}{l}\text { Patgram, } \\
\text { Lalmonirhat }\end{array}$ & 3 & 87.54 & 9 \\
\hline 7. Mahishmari & Sitalkuchi & $\begin{array}{l}\text { Patgram, } \\
\text { Lalmonirhat }\end{array}$ & 54 & 122.77 & 14 \\
\hline 8. Palanpur & Sitalkuchi & $\begin{array}{l}\text { Patgram, } \\
\text { Lalmonirhat }\end{array}$ & 64 & 506.54 & 31 \\
\hline 9. Chhit Land of Jagatbar 3 & Mathabhanga & $\begin{array}{l}\text { Patgram, } \\
\text { Lalmonirhat }\end{array}$ & 37 & 69.84 & 9 \\
\hline 10. Chhit Bhanderdeha & Mathabhanga & $\begin{array}{l}\text { Patgram, } \\
\text { Lalmonirhat }\end{array}$ & 67 & 39.96 & 8 \\
\hline 11. Poaturkuthi & Dinhata & $\begin{array}{l}\text { Lalmonirhat, } \\
\text { Lalmonirhat }\end{array}$ & 37 & 589.94 & 32 \\
\hline 12. Paschim Bakalir Chhara & Dinhata & $\begin{array}{l}\text { Bhurungamari, } \\
\text { Lalmonirhat }\end{array}$ & 38 & 151.98 & 11 \\
\hline 13. Madhya Masaldanga & Dinhata & $\begin{array}{l}\text { Bhurungamari, } \\
\text { Lalmonirhat }\end{array}$ & 3 & 136.66 & 18 \\
\hline 14. Batrigachh I \& II & Dinhata & $\begin{array}{l}\text { Kaligunj, } \\
\text { Lalmonirhat } \\
\end{array}$ & 81 & 577.37 & 34 \\
\hline 15. PurbaMasaldanga I \& II & Dinhata & $\begin{array}{l}\text { Bhurugamari, } \\
\text { Lalmonirhat }\end{array}$ & 11 & 153.89 & 14 \\
\hline 16. KismatBatrigachh & Dinhata & $\begin{array}{l}\text { Kaliganj, } \\
\text { Lalmonirhat }\end{array}$ & 82 & 209.95 & 15 \\
\hline $\begin{array}{l}\text { 17. Dakshin Masaldanga I to } \\
\text { VI }\end{array}$ & Dinhata & $\begin{array}{l}\text { Bhurangamari, } \\
\text { Lalmonirhat }\end{array}$ & 06 & 571.38 & 33 \\
\hline \multicolumn{5}{|c|}{ Total No. of persons interacted with during field survey } & 312 \\
\hline
\end{tabular}

During the field survey conducted in June, 2016 and May, 2017, all three Enclaves Settlement Camps (Rehabilitation Camps) set up in Haldibari, Mekhligunj and Dinhata Blocks under Coochbehar Districts of West Bengal, India, for temporary resettlement of the migrated erstwhile Indian enclaves' people came from Bangladesh were also visited and interacted with total 113 migrated people from Indian enclaves, details of which are shown below under Table 2.

Table 2: Details of Rehab Camps set up for the migrated Indian Enclaves' people visited during field survey

\begin{tabular}{|l|l|l|l|l|l|}
\hline $\begin{array}{l}\text { Name of the } \\
\text { Rehab } \\
\text { Camp } \\
\text { visited }\end{array}$ & $\begin{array}{l}\text { Physically located } \\
\text { in Block \& District } \\
\text { of WB, India }\end{array}$ & $\begin{array}{l}\text { No. of families } \\
\text { accommodated } \\
\text { in the camp }\end{array}$ & $\begin{array}{l}\text { Erstwhile Indian enclaves } \\
\text { wherefrom } \\
\text { migrated }\end{array}$ & $\begin{array}{l}\text { Religion } \\
\text { they }\end{array}$ & $\begin{array}{l}\text { Interacted } \\
\text { with No. of } \\
\text { Migrant } \\
\text { persons }\end{array}$ \\
\hline $\begin{array}{l}\text { 1. Haldibari } \\
\text { Rehab } \\
\text { Camp }\end{array}$ & $\begin{array}{l}\text { Haldibari, } \\
\text { Cooch Behar }\end{array}$ & 96 & $\begin{array}{l}\text { Dohola-Khagrabari, Balapara- } \\
\text { Khagrabari, Najirganj, Salbari }\end{array}$ & All Hindus & 38 \\
\hline
\end{tabular}




\begin{tabular}{|c|c|c|c|c|c|}
\hline $\begin{array}{l}\text { 2. Mekhliganj } \\
\text { Rehab } \\
\text { Camp }\end{array}$ & $\begin{array}{l}\text { Mekhliganj, } \\
\text { Cooch Behar }\end{array}$ & 46 & $\begin{array}{l}\text { Banskata, Lotamari, } \\
\text { Kharkharia, Gotamari Chhit, } \\
\text { Kajaldighi }\end{array}$ & $\begin{array}{l}\text { All Hindus } \\
\text { except one }\end{array}$ & 28 \\
\hline $\begin{array}{l}\text { 3. Dinhata } \\
\text { Rehab } \\
\text { Camp }\end{array}$ & $\begin{array}{l}\text { Dinhata, } \\
\text { Cooch Behar }\end{array}$ & 201 & $\begin{array}{l}\text { Dohola-Khagrabari, } \\
\text { Balapara-Khagrabari, Chhota } \\
\text { Garal Jhora I \& II, Dashier } \\
\text { Chhora }\end{array}$ & $\begin{array}{l}\text { Mostly } \\
\text { Hindus }\end{array}$ & 47 \\
\hline \multicolumn{5}{|c|}{ Total No. of persons interacted with during field survey } & 113 \\
\hline
\end{tabular}

Out of total 111 erstwhile Indian Enclaves in Bangladesh territory, 27 enclaves of different sizes and population bases were randomly chosen for field survey purpose conducted in May, 2015, June, 2016 and May, 2017, at Lalmonirhat, Ponchogarh and Kurigram Districts under Rangpur Division of Bangladesh. Survey had been conducted with total 466 inhabitants of Indian enclaves inside Bangladesh of all ages, genders and religions.

Details of 27 erstwhile Indian enclaves in Bangladesh territory chosen for field survey purpose are shown below under Table 3.

Table 3: Details of Indian Enclaves inside Bangladesh visited during field survey

\begin{tabular}{|c|c|c|c|c|c|}
\hline $\begin{array}{l}\text { Name of erstwhile } \\
\text { Indian enclaves visited }\end{array}$ & $\begin{array}{l}\text { Physically located in the Police } \\
\text { Station \& District in Bangladesh }\end{array}$ & $\begin{array}{l}\text { Under the } \\
\text { jurisdiction } \\
\text { of Indian } \\
\text { Police } \\
\text { Station \& } \\
\text { District }\end{array}$ & $\begin{array}{l}\text { DL } \\
\text { No. }\end{array}$ & $\begin{array}{l}\text { Area in } \\
\text { acres }\end{array}$ & $\begin{array}{l}\text { Interacted } \\
\text { with No. of } \\
\text { Persons in } \\
\text { the enclave }\end{array}$ \\
\hline 1. Balapukhari & Patgram, Lalmonirhat & $\begin{array}{l}\text { Mekhligunj, } \\
\text { Coochbehar }\end{array}$ & 5 & 55.91 & 15 \\
\hline 2. Barakhangir & Patgram, Lalmonirhat & $\begin{array}{l}\text { Mekhligunj, } \\
\text { Coochbehar }\end{array}$ & 4 & 50.51 & 12 \\
\hline 3. Ratnpur & Patgram, Lalmonirhat & $\begin{array}{l}\text { Mekhligunj, } \\
\text { Coochbehar }\end{array}$ & 11 & 58.91 & 14 \\
\hline 4. Bagdogra & Patgram, Lalmonirhat & $\begin{array}{l}\text { Mekhligunj, } \\
\text { Coochbehar }\end{array}$ & 12 & 25.49 & 08 \\
\hline 5. Kharkharia & Patgram, Lalmonirhat & $\begin{array}{l}\text { Mekhligunj, } \\
\text { Coochbehar }\end{array}$ & 15 & 60.74 & 14 \\
\hline 6. Kharkharia & Patgram, Lalmonirhat & $\begin{array}{l}\text { Mekhligunj, } \\
\text { Coochbehar }\end{array}$ & 13 & 51.62 & 10 \\
\hline 7. Lotamari & Patgram, Lalmonirhat & $\begin{array}{l}\text { Mekhligunj, } \\
\text { Coochbehar }\end{array}$ & 14 & 110.92 & 16 \\
\hline 8. Bhotbari & Patgram, Lalmonirhat & $\begin{array}{l}\text { Mekhligunj, } \\
\text { Coochbehar }\end{array}$ & 16 & 205.46 & 18 \\
\hline 9. Panisala & Patgram, Lalmonirhat & $\begin{array}{l}\text { Mekhligunj, } \\
\text { Coochbehar }\end{array}$ & 17 & 137.66 & 13 \\
\hline 10. Panisala & Patgram, Lalmonirhat & $\begin{array}{l}\text { Mekhligunj, } \\
\text { Coochbehar }\end{array}$ & 21 & 51.40 & 09 \\
\hline 11. Lotamari & Patgram, Lalmonirhat & $\begin{array}{l}\text { Mekhligunj, } \\
\text { Coochbehar }\end{array}$ & 20 & 283.53 & 21 \\
\hline 12. Banskata & Patgram, Lalmonirhat & $\begin{array}{l}\text { Mathabhanga, } \\
\text { Coochbehar }\end{array}$ & 112 & 315.04 & 24 \\
\hline 13. Banskata & Patgram, Lalmonirhat & $\begin{array}{l}\text { Mathabhanga, } \\
\text { Coochbehar }\end{array}$ & 113 & 57.86 & 07 \\
\hline
\end{tabular}


PEOPLE: International Journal of Social Sciences

\begin{tabular}{|c|c|c|c|c|c|}
\hline 14. Banskata & Patgram, Lalmonirhat & $\begin{array}{l}\text { Mathabhanga, } \\
\text { Coochbehar }\end{array}$ & 119 & 413.81 & 27 \\
\hline 15. Banskata & Patgram, Lalmonirhat & $\begin{array}{l}\text { Mathabhanga, } \\
\text { Coochbehar }\end{array}$ & 120 & 30.75 & 06 \\
\hline 16. Garati & Ponchogarh, Ponchogarh & $\begin{array}{l}\text { Haldibari, } \\
\text { Coochbehar }\end{array}$ & 75 & 58.23 & 11 \\
\hline 17. Garati & Ponchogarh, Ponchogarh & $\begin{array}{l}\text { Haldibari, } \\
\text { Coochbehar }\end{array}$ & 78 & 958.66 & 31 \\
\hline 18. Nazirganja & Boda, Ponchogarh & $\begin{array}{l}\text { Haldibari, } \\
\text { Coochbehar }\end{array}$ & 41 & 58.32 & 12 \\
\hline 19. Nazirganja & Boda, Ponchogarh & $\begin{array}{l}\text { Haldibari, } \\
\text { Coochbehar }\end{array}$ & 42 & 434.29 & 26 \\
\hline 20. Putimari & Boda, Ponchogarh & $\begin{array}{l}\text { Haldibari, } \\
\text { Coochbehar }\end{array}$ & 59 & 122.80 & 17 \\
\hline 21. Salbari & Boda, Ponchogarh & $\begin{array}{l}\text { Haldibari, } \\
\text { Coochbehar }\end{array}$ & 37 & $\begin{array}{c}1188.9 \\
3 \\
\end{array}$ & 35 \\
\hline 22. Balapara Khagrabari & Debiganj, Ponchogarh & $\begin{array}{l}\text { Haldibari, } \\
\text { Coochbehar }\end{array}$ & 03 & $\begin{array}{c}1752.4 \\
4 \\
\end{array}$ & 33 \\
\hline 23. Gotamari Chhit & Hatibandha, Lalmonirhat & $\begin{array}{l}\text { Sitalkuchi, } \\
\text { Coochbehar }\end{array}$ & 135 & 126.59 & 14 \\
\hline 24. Banspachai & Lalmonirhat, Lalmonirhat & $\begin{array}{l}\text { Dinhata, } \\
\text { Coochbehar }\end{array}$ & 151 & 217.29 & 18 \\
\hline 25. Dasiar Chhora & Phulbari, Kurigram & $\begin{array}{l}\text { Phulbari, } \\
\text { Coochbehar }\end{array}$ & 150 & $\begin{array}{c}1643.4 \\
4\end{array}$ & 38 \\
\hline 26. Chota Garaljhora I & Bhurangamari, Kurigram & $\begin{array}{l}\text { Dinhata, } \\
\text { Coochbehar }\end{array}$ & 148 & 35.74 & 12 \\
\hline 27. Chota Garaljhora II & Bhurangamari, Kurigram & $\begin{array}{l}\text { Dinhata, } \\
\text { Coochbehar }\end{array}$ & 149 & 17.85 & 05 \\
\hline \multicolumn{5}{|c|}{ Total No. of persons interacted with during field survey } & 466 \\
\hline
\end{tabular}

\section{Findings}

A. From the perspective of the people of erstwhile Bangladeshi Enclaves inside India:

17 erstwhile Bangladeshi enclaves inside Indian territory had been randomly chosen for field surveypurpose, which included 06 in Mekhligunj Block, 02 in Sitalkuchi Block, 02 in Mathabhanga Block and 07 in Dinhata Block under Coochbehar District of West Bengal, India. During said field survey, total 312 inhabitants of erstwhile Bangladeshi enclaves of different age, gender and religion were interactedwith,details of them are shown belowunder Table 4 and 5 .

Table 4: Age and Gender-wise classification of the inhabitants of erstwhile Bangladeshi enclaves interacted with during field survey

\begin{tabular}{|l|c|c|c|}
\hline Age group of persons & Male & Female & Total \\
\hline Above 75 years & 17 & 07 & 24 \\
\hline Above 60 to 75 years & 28 & 15 & 43 \\
\hline Above 45 to 60 years & 34 & 23 & 57 \\
\hline Above 30 to 45 years & 45 & 25 & 70 \\
\hline
\end{tabular}




\begin{tabular}{|l|l|l|l|}
\hline Above 20 to 30 years & 42 & 27 & 69 \\
\hline 10 to 20 years & 29 & 20 & 49 \\
\hline Total & $\mathbf{1 9 5}$ & $\mathbf{1 1 7}$ & $\mathbf{3 1 2}$ \\
\hline
\end{tabular}

Table 5: Religion and Gender-wise classification of the inhabitants of erstwhile Bangladeshi enclaves interacted during field survey

\begin{tabular}{|l|c|c|c|}
\hline Religion-wise persons interacted & Male & Female & Total \\
\hline Hindu & 121 & 82 & 203 \\
\hline Muslim & 74 & 35 & 109 \\
\hline Total & $\mathbf{1 9 5}$ & $\mathbf{1 1 7}$ & $\mathbf{3 1 2}$ \\
\hline
\end{tabular}

It was witnessed that the entire population of erstwhile Bangladeshi enclaves inside Indian territory covered under mystudywarmly accepted exchange of enclaves through LBA, 2015, as they got rid of their exiled life of long 67 years within enclaves by means of LBA, 2015. It was evident that all 14,863 residents of erstwhile Bangladeshi enclaves inside India opted for Indian nationality and opted to stay in India as Indian citizen by altering their citizenship ( $M E A$, Exchange of Enclaves between India and Bangladesh, 2015). It was significantly observed that not a single person from erstwhile Bangladeshi enclaves inside India opted to go back to their mother country Bangladesh.

During said field survey, it had been observed that the people of erstwhile Bangladeshi enclaves duly got their Voter ID Card and Aadhar Card from Indian state in support of their identity as Indian Citizen as a part of post-execution of LBA, 2015. Most of them got their Ration Card from the Govt. Some of them got Job Card as well. Some of the erstwhile Bangladeshi enclaves' people were also engaged in 100-days work program of the Govt. No other basic problem of erstwhile Bangladeshi enclaves' people had yet been resolved by the Indian state. No infrastructural developmental works within these enclaves had been noticedand reported during my field survey. Two major challenging issues of erstwhile Bangladeshi enclaves' people had been identified during the fieldsurvey. First and foremost identified issue that enclaves' people were still facing with was relating to settlement of their land records in enclaves. Most of the enclave dwellers anxiously brought the issue of their land record settlement before me when I interacted with them during my field survey. I scrutinized that many enclave dwellers didn't possess the original title deeds of their lands issued by Bangladesh Land Settlement Authority, although these lands were under their possessions for years. During long 
67 years of their exiled life in enclaves, many original land deed holders already sold out their lands to other enclaves' dwellers on the basis of mutual written agreement just on a white paper. Accordingly, such transferee land occupiers didn't not possess original land title deeds on their name; although they were occupying these lands for a long period of time after such transfer took place with consideration. Now, mighty question is that whether such mutual written agreement just on white paper would be considered as valid transfer at the time of disposal of land records and settlements by the Govt. of India. Enclaves' dwellers were really feeling anxiousregarding settlement of their land record issue, which is the only source of generating economic resources of most of enclaves' people till date. Second important identified issue of enclaves' people was availability of job opportunity for them. No job reservation had since been made for the erstwhile enclaves' dwellers, nor had any alternative job opportunity yet been initiated for them by the Indian state. Even for admitting their children into an Indian School or College, enclave dwellers had still been facing with lots of troubles, as no reservation had so far been made for admission of their children. Mr. P. Ulganathan, IAS, the then Hon'bleDistrict Magistrate of Coochbehar District, admitted before me that the key challenge to resolve erstwhile Bangladeshi enclaves' problem was disposal of land records and settlements.

Classified opinions regarding exchange of enclaves and LBA, 2015 post-execution status of erstwhile enclaves' people of total 312 inhabitants of erstwhile Bangladeshi enclaves interacted with during my field survey are shown below under Table 6.

Table 6: Classified Opinions of 312 inhabitants of erstwhile Bangladeshi enclaves regarding exchange of enclaves and their status during post-execution of LBA, 2015

\begin{tabular}{|l|c|c|c|}
\hline Summarized Opinions & Yes & No & Total \\
\hline 1. Whether accepted exchange of enclaves through LBA, 2015 & 312 & 00 & 312 \\
\hline 2. Whether satisfied about their decision regarding choice of citizenship & 306 & 06 & 312 \\
\hline 3. Whether they feel safe as being Indian citizen & 312 & 00 & 312 \\
\hline 4. Whether satisfied about infrastructural development within enclaves & 00 & 312 & 312 \\
\hline 5. Whether satisfied about basic identities \& facilities provided to them & 29 & 283 & 312 \\
\hline 6. Whether satisfied about rehabilitation packages provided to them & 00 & 312 & 312 \\
\hline 7. Whether expecting more rehabilitation packages from the Indian State & 305 & 07 & 312 \\
\hline 8. Whether prefer to migrate in Bangladesh & 00 & 312 & 312 \\
\hline
\end{tabular}

B. From the perspective of the migrated people of erstwhile Indian Enclaves came from Bangladesh temporarily resettled at Enclave Settlement Camps in India: 
As per report of the joint survey conducted by India and Bangladesh in erstwhile enclaves of both the countries, it had been evident that 989 persons, out of total 38,521 residents of erstwhile Indian enclaves in Bangladesh, opted to retain their original nationality of Indian citizenship and migrated them to Indian mainland from Bangladesh (MEA, Exchange of Enclaves between India and Bangladesh, 2015). During said field survey conducted in June, 2016 and in May, 2017, all the three Enclave Settlement Camps set up in India for temporary resettlement of migrated erstwhile Indian enclaves' people came from Bangladesh were also visited. These camps were located in Haldibari, Mekhligunj and Dinhata Blocks under Coochbehar District of West Bengal, India. In these camps, total 113 migrated inhabitants of erstwhile Indian enclaves of different ages, gender and religion were interacted with, which included 38 from Haldibari Camp, 28 from Mekhligunj Camp and 47 from Dinhata Camp. Details of them are given below under Table 7 and 8.

Table 7: Age and Gender-wise classification of inhabitants of erstwhile Indian enclaves temporarily resettled in Enclaves Settlement Camps in India interacted with

\begin{tabular}{|l|c|c|c|}
\hline Age group of persons & Male & Female & Total \\
\hline Above 75 years & 03 & 01 & 04 \\
\hline Above60 to 75 years & 08 & 03 & 11 \\
\hline Above 45 to 60 years & 13 & 07 & 20 \\
\hline Above 30 to 45 years & 19 & 13 & 32 \\
\hline Above 20 to 30 years & 20 & 16 & 36 \\
\hline 10 to 20 years & 06 & 04 & 10 \\
\hline Total & $\mathbf{6 9}$ & $\mathbf{4 4}$ & $\mathbf{1 1 3}$ \\
\hline
\end{tabular}

Table 8: Religion and Gender-wise classification of inhabitants of erstwhile Indian enclaves temporarily resettled in Enclaves Settlement Camps interacted with

\begin{tabular}{|l|c|c|c|}
\hline Religion-wise persons interacted & Male & Female & Total \\
\hline Hindu & 60 & 40 & 100 \\
\hline Muslim & 09 & 04 & 13 \\
\hline Total & $\mathbf{6 9}$ & $\mathbf{4 4}$ & $\mathbf{1 1 3}$ \\
\hline
\end{tabular}

During my field survey, it was evident that thewhole population of migrated people of erstwhile Indian enclaves came from Bangladesh too genially accepted exchange of enclaves 
through LBA, 2015, as they got rid of their exiled life of long 67 years in enclaves by means of LBA, 2015

During said field survey, it had been observed that the migrated people of erstwhile Indian enclaves from Bangladesh duly got their Voter ID Card and Aadhar Card in support of their identity as Indian Citizen in Indian mainland. Govt. of India arranged temporary accommodations for them by setting up three Enclaves Settlement Camps with free electricity facility and also provided them some essential food commodities (Rice, Mustard Oil, Kerosene, Salt, Milk and Pulse) at free of cost. Most of them also got Job Card and Ration Card from the Indian state.Some of the migrated Indian enclaves' people were also engaged in 100-days work program of the India Govt.It had been reported by the local civil administration that lands had been identified by the Govt. for permanent resettlement of these people. But, migrated people of Indian enclaves, who came from Bangladesh, were really frightened about their permanent settlement in Indian mainland. No job reservation had since been made for these migrated erstwhile Indian enclaves' people temporarily resettled at said Enclave Settlement Camps; nor had any alternative job opportunity yet been initiated for them. They were feeling confused about their decision regarding their migration in Indian mainland. In erstwhile Indian enclaves inside Bangladesh territory, where they lived in during last 67 years, they had their own lands for cultivation and they could move to Bangladeshi land in search of their bread and butter. According to them, they could hardly get any opportunity for finding any suitable job after migrating in Indian mainland, where they are now completely 'landless' as well as 'jobless'. Many of them couldn't even sale their property that they had in Indian enclaves in Bangladesh. "A year after enclave dwellers got Indian citizenship, several of these people want to go back to Bangladesh as they are miffed over the lack of job and other opportunities in India. According to PTI, Those who have come from Indian enclaves which were situated in Bangladesh are feeling alienated here. They don't have either any job opportunities or any proper source of income. How will they secure their future? So they feel that going back to Bangladesh is the best option to secure their future"(Express, 2017). I too witnessed above feelings of the migrated erstwhile Indian enclaves' people during my said field survey. No permanent shelter had yet been provided to them; nor had any permanent jobopportunity been procured for them so far in Indian mainland. As no reservation had since been made, migrated erstwhile Indian enclaves' people had been facing with lots of problems for admitting their children into an Indian School or College. Although, procurement of permanent shelter for the migrated erstwhile Indian enclaves' 
people was under process as reported by the then Hon'ble District Magistrate, District of Coochbehar, Mr. P. Ulganathan, IAS. He assured me that adequate funds would be released by the Govt. of India for resettlement and rehabilitation of migrated and non-migrated erstwhile enclaves' people.

Classified opinions regarding exchange of enclaves and LBA, 2015 post-execution status of erstwhile enclaves' people of total 113 migrated inhabitants of erstwhile Indian enclaves temporarily resettled in Enclaves Settlement Camps interacted with during my field survey are shown below under Table - 9 :

Table 9: Classified Opinions of 113 inhabitants of erstwhile Indian enclaves temporarily resettled in Enclaves Settlement Camps interacted with during the field survey regarding exchange of enclaves and their status during post-execution of LBA, 2015

\begin{tabular}{|l|c|c|r|}
\hline Summarized Opinions & Yes & No & Total \\
\hline 1. Whether accepted exchange of enclaves through LBA, 2015 & 113 & 00 & 113 \\
\hline 2. Whether satisfied about their decision regarding choice ofcitizenship & 33 & 80 & 113 \\
\hline 3. Whether they feel safe as being Indian citizen & 77 & 36 & 113 \\
\hline 4. Whether satisfied about rehabilitation packages provided to them & 11 & 102 & 113 \\
\hline 5. Whether satisfied about basic identities \& facilities provided to them & 15 & 98 & 113 \\
\hline 6. Whether expecting more rehabilitation packages from the Indian State & 113 & 00 & 113 \\
\hline 7. Whether prefer to go back to Bangladesh & 52 & 61 & 113 \\
\hline
\end{tabular}

C. From the perspective of the people of erstwhile Indian Enclaves inside Bangladesh:

27 erstwhile Indian enclaves in Bangladesh territory had been randomly chosen for field sample survey purpose, which included 17 in Lalmonirhat District, 07 in Ponchogarh District and 03 in Kurigram District in Bangladesh. During said field survey, total 466 inhabitants of erstwhile Indian enclaves of different ages, gender and religion were interacted with, the details of them are shown below under Table 10and 11.

Table 10: Age and Gender-wise classification of the inhabitants of erstwhile Indian enclaves in Bangladesh interacted with during field survey

\begin{tabular}{|l|c|c|c|}
\hline \multicolumn{1}{|c|}{ Age group of persons } & Male & Female & Total \\
\hline Above 75 years & 18 & 10 & 28 \\
\hline Above 60 to 75 years & 43 & 21 & 64 \\
\hline Above 45 to 60 years & 67 & 39 & 106 \\
\hline Above 30 to 45 years & 76 & 45 & 121 \\
\hline
\end{tabular}




\begin{tabular}{|l|c|c|c|}
\hline Above 20 to 30 years & 58 & 34 & 92 \\
\hline 10 to 20 years & 36 & 19 & 55 \\
\hline Total & $\mathbf{2 9 8}$ & $\mathbf{1 6 8}$ & $\mathbf{4 6 6}$ \\
\hline
\end{tabular}

Table 11: Religion and Gender-wise classification of the inhabitants of erstwhile Indian enclaves in Bangladesh interacted during field survey

\begin{tabular}{|l|c|c|c|}
\hline \multicolumn{1}{|c|}{ Religion-wise persons interacted } & Male & Female & Total \\
\hline Hindu & 22 & 14 & 36 \\
\hline Muslim & 276 & 154 & 430 \\
\hline Total & $\mathbf{2 9 8}$ & $\mathbf{1 6 8}$ & $\mathbf{4 6 6}$ \\
\hline
\end{tabular}

It was witnessed that the entire population of erstwhile Indian enclaves inside Bangladesh covered under the study tenderly accepted exchange of enclaves through LBA, 2015, as they got rid of their exiled life of long 67 years within enclaves through LBA, 2015. It had been evident that 989 persons, out of total 38,521 residents of erstwhile Indian enclaves in Bangladesh, opted to retain their original nationality of Indian citizenship and migrated to Indian mainland from Bangladesh. Remaining 37,532 residents of erstwhile Indian enclaves in Bangladesh opted to stay in Bangladesh as Bangladeshi Citizen by altering their nationality (MEA, Exchange of Enclaves between India and Bangladesh, 2015).

During my field survey, it had been observed that the people still staying in erstwhile Indian enclaves inside Bangladesh duly got their Citizenship Identity Card in support of their identity as Bangladeshi Citizen from the Govt. of Bangladesh. Lands in erstwhile Indian enclaves had duly been recorded by the Bangladesh Land Record Authority in the name of respective owners of enclaves' lands. Enough infrastructural development works within erstwhile Indian enclaves had been noticed during my field survey. Electricity supply line had been extended up to the doorstep of the enclaves' dwellers in almost all the erstwhile Indian enclaves. Schools and Madrasas had already been established in all large and medium size Indian enclaves in Bangladesh. Roads within these enclaves had been demarcated and measured, and construction works had already been initiated in many enclaves. Boring Tube well had been installed for supplying drinking water and water for agricultural purpose in most of the enclaves. Latrine within residential house had been constructed by the Bangladesh Govt. at free of cost in many enclaves. Most of the senior enclaves' dwellers having 55 years or more age were getting old age pension@ @ Bangladeshi Taka 500/= per month per head from Govt. of Bangladesh. Govt. 
of Bangladesh hadalready sanctioned funds for setting up Health Centre and School for Physically Challenged Persons in some of the large size erstwhile Indian enclaves. But no job reservation policy has since been made for these erstwhile enclaves' dwellers, nor has any alternative job opportunity yet been initiated for them by the Govt. of Bangladesh.

Classified opinions regarding exchange of enclaves and LBA, 2015 post-execution status of erstwhile enclaves' people of total 466 inhabitants of erstwhile Indian enclaves in Bangladesh interacted with during the field survey are shown below under Table 12.

Table 12: Classified Opinions of 466 inhabitants of erstwhile Indian enclaves in Bangladesh interacted with during the field survey regarding exchange of enclaves and their status during post-execution of LBA, 2015

\begin{tabular}{|l|l|l|r|}
\hline \multicolumn{1}{|c|}{ Summarized Opinions } & Yes & No & Total \\
\hline 1. Whether accepted exchange of enclaves through LBA, 2015 & 466 & 00 & 466 \\
\hline 2. Whether satisfied about their decision regarding choice ofcitizenship & 379 & 87 & 466 \\
\hline 3. Whether they feel safe as being Bangladeshi citizen & 401 & 65 & 466 \\
\hline 4. Whether satisfied about basic identities \& facilities provided to them & 392 & 74 & 466 \\
\hline 5. Whether satisfied about rehabilitation packages provided to them & 377 & 89 & 466 \\
\hline 6. Whether expecting more rehabilitation packages from the BD State & 445 & 21 & 466 \\
\hline 7. Whether satisfied about infrastructural development within enclaves & 446 & 20 & 466 \\
\hline 8. Whether prefer to migrate in India & 76 & 390 & 466 \\
\hline
\end{tabular}

\section{Conclusion}

Fragmented territories within the two countries created an inhuman situation for survival of enclaves' people and they were nastilyvictimized of historical and political mockery for sustaining their existence in such inhuman situation of statelessness without any Governmental support and basic amenities for their livelihoods during past 67 years after India's independence and partition. A porous political border ultimatelysnatchedmany golden moments from their lives making them just 'nowhere people' under the sky. In the meantime, plenty of water has blown down the river Tista. LBA, 2015 had been accorded with between the two concerned nations for settlement of this long overdue acute problem and finally exclaves were exchanged between India and Bangladesh. As per report of the joint survey conducted by India and Bangladesh in erstwhile enclaves of both the countries, it had been evident that 989 persons, out of total 38,521 residents of erstwhile Indian enclaves in Bangladesh, opted to retain their original nationality of Indian citizenship and migrated to Indian mainland from Bangladesh. On the other hand, all 
14,863 residents of the Bangladeshi enclaves in India opted for Indian nationality and opted to stay in India as Indian citizen by altering their citizenship(MEA, Exchange of Enclaves between India and Bangladesh, 2015). Both the countries duly provided Citizenship Identity Card to the erstwhile enclaves' people opted to stay within the territory of the concerned state. Govt. of Bangladesh already initiated lots of infrastructural developmental works within erstwhile Indian enclaves; whereas Govt. of India could do little infrastructural developmental works within erstwhile Bangladeshi enclaves so far. No job reservation policy had since been initiated for the erstwhile enclaves' people by the concerned Govt. of both the countries, nor had any alternative job opportunity yet been procured for them by both the concerned states. Migrated people of Indian enclaves came from Bangladesh temporarily rehabilitated in Enclaves Settlement Camps had been sustaining their lives with anxiety of uncertain future permanent resettlement and adequate job opportunity in Indian mainland. But, all the challenging issuesin erstwhile enclaves, especially in erstwhile Bangladeshi enclaves in India and in case of migrated people of Indian enclaves from Bangladesh,had not yet been resolved by the concerned state. All these erstwhile enclaves' people were still feeling anxious about their future re-settlement and re-establishment even after conquering the battle for their statehood-ship. .

\section{References}

Bhattacharya, D. (2017). A Rarely Told Gloomy Saga of Resurrected Nowhere People Earlier Lived in No-man's Land. IOSR Journal of Humanities and Social Science, 2332.https://doi.org/10.9790/0837-2202052332

Bhattacharya, D. (2017). Comparative Impact of Execution of Land Boundary Agreement, 2015 between India and Bangladesh on the status of Erstwhile Enclaves' People. Journal of South Asian Studies, 77-87.

Bhattacharya, D. (2017). Land Boundary Agreement, 2015 between India and Bangladesh - a Post-Implementation Analysis from India's Perspective. Quest Journal of Research in Humanities \& Social Science, 26-33.

Bhattacharya, D. (2017). Study on Impact of Exclusion of Exchange of Dohogram-Angarpota Bangladeshi Enclave from the Coverage of Land Boundary Agreement, 2015. International Journal of Research in Economics and Social Sciences, 74-85. 
Butalia, U. (2002). http://www.india-seminar.com/2002/510/510\%20urvashi\%20butalia.htm.

Retrieved from www.india-seminar.com: http://www.indiaseminar.com/2002/510/510\%20urvashi\%20butalia.htm

Chatterjee, S. (2011).International Border Disputes \& Adverse Possessions of India-Bangladesh Border.New Blaze.

Corridor, T. B.

(2008).https://www.revolvy.com/main/index.php?s=Teen\%20Bigha\%20Corridor\&item_t ype=topic. Retrieved from www.revolvy.com: https://www.revolvy.com/main/index.php?s=Teen\%20Bigha\%20Corridor\&item type=to pic

Das, R. \&. (2013, August 13). A long settlement overdue. The Hindu .

Encyclopedia, W. H. (2010).Chitmahal. Retrieved from www.self.gutenberg.org: http://self.gutenberg.org/articles/eng/Chitmahal

Express, T. I. (2017, January 23). Failed promises : A year on, some enclave dwellers want to return to Bangladesh. The Indian Express .

Faculty of Studies, B. A. (2001).Surveillance \& Security of Borders. New Delhi: BSF, India.

Jugantor.(2015). Report of Jugantor. Dhaka: Bangladeshi Newspaper.

Kaur, N. (2002, June 8-21). The Nowhere People. Frontline , pp. Vol. 19, Issue 12.

MEA, P. R. (2015). Exchange of Enclaves between India and Bangladesh. New Delhi: Ministry of External Affairs, Govt. of India.

MEA, P. R. (2015). Exchange of Enclaves between India and Bangladesh. New Delhi: Ministry of External Affairs, Govt. of India.

MEA, P. R. (2015). India-Bangladesh Land Boundary Agreement. New Delhi: Ministry of External Affairs, Govt. of India.

MEA, P. R. (2011). Land Boundary Agreement Protocol between India and Bangladesh. New Delhi: Ministry of External Affairs, Govt. of India.

MEA, P. R. (2011). Land Boundary Agreement Protocol between India and Bangladesh. New Delhi: Ministry of External Affairs, Govt. of India.

Press Release, M. o. (2015).Exchange of Enclaves between India and Bangladesh. New Delhi: Govt. of India.

Rabbani, M. G. (2005-06). Statelessness in South Asia: Living in Bangladesh-India Enclaves. Theoretical Perspectives. 
Report, J. F. (1996).Report of the India- Bangladesh Joint Field Inspection. New Delhi: Ministry of External Affairs, Govt. of India.

Schendel, W. V. (2005). The Bengal Borderland. London: Anthem Press.

Service, E. N. (2013, July 20). India, Bangladesh discuss boundary, enclaves issues. New Delhi: The Indian Express.

Studyacer.(2010). https://studyacer.com/problem/chhit-mahals-of-india-and-bangladesh2787393. Retrieved from www.studyacer.com: https://studyacer.com/problem/chhitmahals-of-india-and-bangladesh-2787393 